\title{
Images of Exile in the Prophetic Literature
}

\author{
Copenhagen Conference Proceedings 7-10 May 2017 \\ Ed. by Jesper Høgenhaven, Frederik Poulsen, and Cian Power
}

[Bilder des Exils in der prophetischen Literatur. Tagungsband zur Konferenz in Kopenhagen, 7.-10. Mai 2017.]

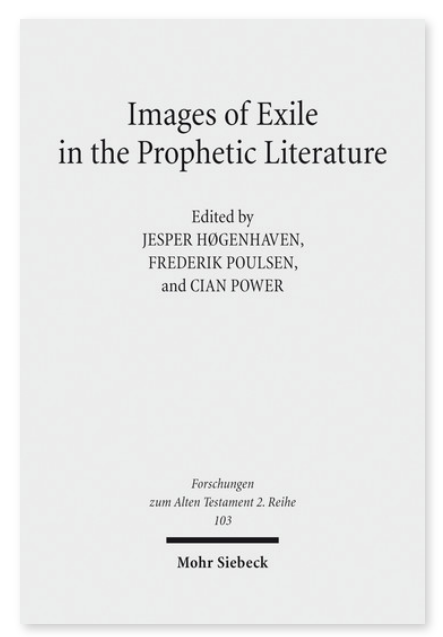

2019. VI, 289 pages. FAT II 103

ISBN 978-3-16-155749-1 sewn paper $99,00 €$ ISBN 978-3-16-156699-8 eBook PDF $99,00 €$
Published in English.

Exile is a central concern in the Hebrew Bible. The fifteen essays in this volume, presented at an international conference in Copenhagen in May 2017, investigate and discuss images of exile in the prophetic books. Some deal with a specific passage or biblical book, while others approach the issue by comparing different books or by looking more closely at a particular metaphor or theme. The first group of essays focuses on exile in Isaiah, while the second group treats this topic in Jeremiah and Ezekiel as well as possible links between the two books. The third group consists of various studies, including nature and agricultural imagery for exile, deportations from the Northern Kingdom, and the prophet Jonah as a perpetual refugee. A recurrent question is what role language and metaphors play in the prophets' attempts to express, structure, and cope with experiences of exile.

\section{Survey of contents}

Jesper Høgenhaven/Frederik Poulsen/Cian Power: Introduction: Images of Exile in the Prophetic Literature

\section{Part I: Isaiah}

Francis Landy: Metaphors for Death and Exile in Isaiah - Frederik Poulsen: The Trope of Scattering in Isaiah: A Reading of Isaiah 11:11-16 and 27:7-13 - Hyun Chul Paul Kim: Metaphor, Memory, and Reality of the »Exile« in Deutero-Isaiah - Ulrich Berges: The Individualization of Exile in Trito-Isaiah: Some Reflections on Isaiah 55 and 58

\section{Part II: Jeremiah and Ezekiel}

Paul M. Joyce: A Rebirth of Images? Theme and Motif in Jeremiah and Ezekiel - Else K. Holt: Leave or Remain? A Theological Discussion in Jeremiah 29 and Beyond - Martien A. Halvorson-Taylor: Prophetic Images of Women as Metaphors for Exile: Jeremiah's Book of Consolation - Sonja Ammann: Voting with One's Feet: Emigration as a Matter of Choice in the Jeremiah Narratives - Jesper Høgenhaven: Departure and Return of the Divine Glory in Ezekiel? - Søren Holst: "You Shall Never Be Clean Again Until I Have Satisfied My Fury Upon You« (Ezek 23:13): Exile, Impurity, and Purification in Ezekiel - Anja Klein: Uncovering the Nymphomaniac: The Verb גלה and Exile as Sexual Violence in Ezekiel 16 and 23

Part III: Various Themes

Dalit Rom-Shiloni: Nature Imagery within Images of Exile: General Survey and Metaphoric Functions - Göran Eidevall: Trees and Traumas: On the Use of Phytomorphic Metaphors in Prophetic Descriptions of Deportation and Exile - Cian Power: Images of Northern Exile: The Deportations from the Kingdom of Israel in the Prophets - Lena-Sofia Tiemeyer: Jonah, the Eternal Fugitive: Exploring the Intertextuality of Jonah's Flight in the Bible and Its Later Reception

Jesper Høgenhaven Born 1961; 1988 Dr. theol. (Copenhagen); since 2007 Professor of Old Testament at the University of Copenhagen.

Frederik Poulsen Born 1984; 2014 PhD; currently Assistant Professor of Old Testament at the University of Copenhagen.

Cian Power Born 1987; 2015 PhD, Harvard University; 2016-18 Postdoctoral Research Fellow, Uppsala University; currently lecturer in Ancient Hebrew Language at the Faculty of Theology and Religion, University of Oxford.

https://orcid.org/0000-0001-8513-5243

\section{Order now:}

https://www.mohrsiebeck.com/en/book/images-of-exile-in-the-prophetic-literature-9783161557491?no_cache=1 order@mohrsiebeck.com Phone: +49 (0)7071-923-17 Fax: $+49(0) 7071-51104$ 